\title{
How long should the fully hillside-closed forest protection be implemented on the Loess Plateau, Shaanxi, China?
}

\author{
Lin Hou Corresp., 1 , Sijia Hou ${ }^{2}$ \\ ${ }^{1}$ College of Forestry, Northwest A\&F University, Yangling, Shaanxi, China \\ 2 College of Transportation, Southeast University, Nanjing, Jiangsu, China \\ Corresponding Author: Lin Hou \\ Email address: houlin1969@163.com
}

Background. Restoration of degraded forest ecosystem is crucial for regional sustainable development. To protect the country's fragile and fragmented environment, the Chinese government has initiated an ecological engineering, the Natural Forest Protection Program in seventeen provinces in China since 1998. Fully hillside-closed forest protection (vegetation restoration naturally without any artificial disturbance) was one of vital measures of the Natural Forest Protection Program applied national wide. Whether plant diversity, biomass and age structure of dominant tree species and soil nutrients in protected stands may become better with increase of protected period are still open problems. Methods. We investigated community diversity, biomass of dominant tree species, age structures, and analyzed soil chemical properties of a Pinus tabulaeformis population at protected sites representing different protected ages at Huanglongshan Forest Bureau on the Loess Plateau, Shaanxi, China. Results. Plant species richness of Pinus tabulaeformis community was significantly affected $(p<0.05)$ by forest protection and the effect attenuated with protection age.Shannon evenness index of plant species generally increased with protection age. Stands protected for 45 years had the highest tree biomass and considerable natural regeneration capacity. Contents of organic carbon, available phosphorus and available potassium in top soil increased in protected stands less than 45 years, however decreased significantly thereafter. Long-term forest protection also decreased content of mineral nitrogen in top soil. Discussion. We found that richness of shrubs and herbs was significantly affected by forest protection, and evenness indices of tree, shrub and herb increased inconsistently with protected ages. Forest protection created more complex age structures and tree densities with increasing age of protection. Content of soil mineral nitrogen at $0-20 \mathrm{~cm}$ soil depth showed a decreasing trend in stands of up to 30 years. Soil available phosphorus and potassium contents were higher in stands with greater proportions of big and medium trees. Long-term protection ( $>45$ years) of Pinus tabulaeformis stand in southeast Loess Plateau, China, may be associated with 
decreasing plant species richness, proportion of medium to large trees, dominant biomass of Pinus tabulaeformis and soil nutrients. 
1 How long should the fully hillside-closed forest protection be implemented on

2 the Loess Plateau, Shaanxi, China?

3

Lin $\mathrm{Hou}^{1}$, Sijia Hou ${ }^{2}$

41 College of Forestry, Northwest A\&F University, Yangling, Shaanxi 712100, China

52 College of Transportation, Southeast University, Nanjing, Jiangsu, 211189, China

6

7

8

9

10

11

12

19 Corresponding author

20 Lin Hou

213 Taicheng Road, Yangling, Shaanxi, 712100, China 
Abstract

Background. Restoration of degraded forest ecosystem is crucial for regional sustainable development. To protect the country's fragile and fragmented environment, the Chinese government has initiated an ecological engineering, the Natural Forest Protection Program in seventeen provinces in China since 1998.Fully hillside-closed forest protection (vegetation restoration naturally without any artificial disturbance) was one of vital measures of the Natural Forest Protection Program applied national wide. Whether plant diversity, biomass and age structure of dominant tree species and soil nutrients in protected stands may become better with increase of protected period are still open problems.

Methods. We investigated community diversity, biomass of dominant tree species, age structures, and analyzed soil chemical properties of a Pinus tabulaeformis population at protected sites representing different protected ages at Huanglongshan Forest Bureau on the Loess Plateau, Shaanxi, China.

Results. Plant species richness of Pinus tabulaeformis community was significantly affected $(p<0.05)$ by forest protection and the effect attenuated with protection age. Shannon evenness index of plant species generally increased with protection age. Stands protected for 45 years had the highest tree biomass and considerable natural regeneration capacity. Contents of organic carbon, available phosphorus and available potassium in top soil increased in protected stands

41 less than 45 years, however decreased significantly thereafter. Long-term forest protection also decreased content of mineral nitrogen in top soil. 
43 Discussion. We found that richness of shrubs and herbs was significantly affected by forest

44 protection, and evenness indices of tree, shrub and herb increased inconsistently with protected ages. Forest protection created more complex age structures and tree densities with increasing age of protection. Content of soil mineral nitrogen at $0-20 \mathrm{~cm}$ soil depth showed a decreasing trend in stands of up to 30 years. Soil available phosphorus and potassium contents were higher in stands with greater proportions of big andmedium trees. Long-term protection ( $>45$ years) of Pinus tabulaeformisstand in southeast Loess Plateau, China, may be associated with decreasing plant species richness, proportion of medium to large trees, dominant biomass of Pinus tabulaeformis and soil nutrients. 


\section{INTRODUCTION}

65 Ecological restoration is being recognized as an international priority (Aronson \&

Alexander 2013; Wortley et al. 2013) and it plays a crucial role in rebuilding ecological equilibrium and reversing ecosystem degradation (Ma et al. 2013). As a part of ecological engineering (Mitsch 2012), the practice is being widely incorporated into natural resource strategies from the local to global level (Wortley et al. 2013).

To protect the country's fragile and fragmented environment, the Chinese government has initiated an ecological engineering, the Natural Forest Protection Program (NFPP) since 1998 (Xu et al. 2006). Logging and harvesting of partial or full timber was prohibited in protected areas from 1998 to 2008 (Xu et al. 2006). Fully hillside-closed forest protection (vegetation restoration naturally without any artificial disturbance) was applied nation-wide. Ecosystems have the capacity to self-organize and the self-design or self-organizational properties of natural systems is an essential component to ecological engineering (Bergen et al. 2001).Obviously, fully hillside-closed forest protection is in accord with the ecological engineering principle selfdesign.

The previous studies regarding NFPP have mainly focused upon the introduction of the related policy issues, the spatial-temporal succession of regional vegetation (Huang et al. 2014) and ecological restoration programs and payments (Yin \& Zhao 2012). However, a range of questions remain, particularly in relation to stand function and associated environmental parameters following stand protection. We hypothesize that fully hillside-closed forest protection may promote plant diversity, biomass and age structure of dominant tree species and soil 
nutrients with increase of protected period. The objectives of this study are to address a few of these key knowledge gaps, including : (i) do the stands exhibit significant differences in plant assemblage; (ii) does soil fertility change with stand age structure;(iii) can a functional relationship be defined regarding length of stand protection and stand quality, i.e., are stands protected for longer timeframes "better" than other stands; and (iv) based on findings of i-iii above, can a preliminary estimate regarding the optimal time span for Pinus tabulaeformisstands be recommended to the Natural Forest Protection Program?

\section{MATERIALS AND METHODS}

\section{Site description}

The study was conducted in Huanglong County $\left(35^{\circ} 28^{\prime} 49^{\prime \prime}-36^{\circ} 02^{\prime} 01^{\prime \prime} \mathrm{N}, 109^{\circ} 38^{\prime} 49^{\prime \prime}-\right.$ $\left.110^{\circ} 12^{\prime} 47^{\prime \prime} \mathrm{E}\right)$ on the southeast Loess Plateau, Shaanxi, China. Stands in this area (a part of NFPP area) play key ecological roles in abatement of soil erosion and mitigation of sand storm (Chen et al. 2014). The vegetation type is a northern deciduous broad-leaved forest sub-region. Pinus tabulaeformis is dominant tree species in the currently existing stands. The associated tree species are Quercus liaotungensis, Syringa oblate, Populus davidiana, Prunus davidiana, Betula platyphylla and Toxicodendron vernicifluum. Shrubs and herb species in understory are abundant.

The altitude ranges from 1100 to $1300 \mathrm{~m}$. It is dominated by a warm temperate and semi-humid continental climate. The annual average precipitation is $612 \mathrm{~mm}$ and the mean atmospheric temperature is $8.6^{\circ} \mathrm{C}$. Cinnamon soil is the main soil type in the forest region. Due to poor communication and a small human population in the past years, stands on some special sites have not been disturbed since 1950, especially since 1998. We consulted forest resource archive 
106

107

108

109

110

111

112

data of Huanglongshan Forest Bureau, Yanan, Shaanxi, China to find the year of forest

protection and chose plots from forest farms (Figure 1).According to the data, stands with protected age sequences were found in four forest farms (Table 1).

\section{Field methods}

We chose plots randomly. To find typical stand plots in the same protected age, not only similar altitude and canopy density, but also various directions, gradients, positions and density of dominant tree species were considered as principles. The field investigation and sampling was conducted between June 5 to July 15, 2003. Each plot of trees, shrubs and herbs was $20 \mathrm{~m} \times 20$

$\mathrm{m}, 2 \mathrm{~m} \times 2 \mathrm{~m}$ and $1 \mathrm{~m} \times 1 \mathrm{~m}$ respectively. Five sub-plots of shrubs, herbs and regenerating seedlings were arrayed diagonally in each tree plot respectively (Figure 2). The indices, species, number, Height $(\mathrm{H})$, diameter at breast height $(\mathrm{DBH})$ and canopy density of trees, and species, height, cover ratio, number of shrubs, herbs and regenerating seedlings were measured. All community data were collected from 27 tree plots spreading among the age cohorts and 270 subplots (Table 1). Three soil samples were obtained randomly by a special drill in each tree plot. Surface soils (0-20cm depth) at all sites were assessed for soil properties including organic carbon, mineral $\mathrm{N}$, available phosphorous and potassium.

\section{Community diversity}

The diversity-productivity relationship (DPR) has been paid much attention during the past two decades (Hooper et al. 2005). In most DPR studies, richness has been chosen as the index of species diversity to define and interpret DPRs (Zhang et al. 2012). However, the simplex index cannot completely represent species diversity (Bock et al. 2007) in relation to ecosystem 
127 functioning for its ignoring the effect of species evenness on interspecific interactions

128 (Hillebrand et al. 2008; Kirwan et al. 2007; Turnbull \& Hector 2010). Based on 54 studies, the

129

130

131

132

133

134

135

136

137

138

139

140

141

142

143

144

145

146

147 importance of species richness and evenness in influencing diversity-associated productivity has been demonstrated in a meta-analysis (Zhang et al. 2012). In this study, we chose indices of richness and evenness to reflect characteristics of community. Species richness index (S) was derived from field survey data. To characterize the diversity of the stand community, the Shannon-Wiener index $\left(H^{\prime}\right)$ and evenness index $\left(J^{\prime}\right)$ were calculated as the following:

$$
\text { Shannon-Wiener index } \quad H^{\prime}=-\sum P_{i} \ln P_{i}
$$

Shannon evenness index $\quad J^{\prime}=\frac{H^{\prime}}{\ln S}$

where $P_{i}$ is the relative frequency of the i-th species, and $S$ is total number of species in plots and subplots (Magurran 2004).

\section{Biomass of dominant tree species}

Average DBH (cm) and height (m) of Pinus tabulaeformis in each plot were calculated and living biomass $\left(\mathrm{Mgha}^{-1}\right)$ of whole trees (Pinus tabulaeformis) were estimated according to literatures (Chen \& Peng 1996; Pan et al. 2004).

$$
\begin{aligned}
& \mathrm{Y}=15.525+0.6269 \mathrm{v} \\
& \ln v=0.99138 \ln \left(D^{2} H\right)-10.30211
\end{aligned}
$$

where $Y$ is the living biomass of trees $\left(\mathrm{Mgha}^{-1}\right), v$ is the stand growing stock $\left(\mathrm{m}^{3} \mathrm{ha}^{-1}\right), D(\mathrm{~cm})$ is diameter at breast height and $H(\mathrm{~m})$ is height.

Combining the density of dominant tree species (Table 1) with equations, biomass of Pinus tabulaeformisin protected stands was determined. 


\section{Age structures}

$\mathrm{DBH}$ of tree species correlate significantly to their ages under the same environmental condition (Parker \& Peet 1984). Lacking of analytic wood data, we adopted DBH structures of Pinus tabulaeformis population instead of its age structures. Combining DBH and $\mathrm{H}$, age structures of Pinus tabulaeformis population were classified as following: I seedling, $\mathrm{H} \leq 0.30 \mathrm{~m}$; II young tree, $0.30 \mathrm{~m}<\mathrm{H} \leq 2.00 \mathrm{~m}, \mathrm{DBH} \leq 6.00 \mathrm{~cm}$; III small tree, $\mathrm{H}>2.0 \mathrm{~m}, 6.0 \mathrm{~cm}<\mathrm{DBH} \leq 12.0 \mathrm{~cm}$;

IV medium tree, $12.0 \mathrm{~cm}<\mathrm{DBH} \leq 20.0 \mathrm{~cm} ; \mathrm{V}$ big tree, $\mathrm{DBH}>20.0 \mathrm{~cm}$. The ratio of seedlings, young trees, small trees, medium trees and big trees in stand with same protecting age was used to illustrate age structures. Probable age of individual was determined by their whorled branches.

\section{Chemical analyses}

Analyses were made on air-dry soil material that passed through a $2 \mathrm{~mm}$ sieve. Soil organic carbon content (SOC) was determined by dry combustion with a TOC/TON analyzer (TOC-

VTH-2000A, Shimadzu Corporation, Japan). Soil mineral nitrogen (ammonium nitrogen, $\mathrm{NH}^{+}{ }_{4}^{-}$ $\mathrm{N}$ and nitric nitrogen, $\mathrm{NO}^{-}{ }_{3}-\mathrm{N}$ ) content was determined by the colorimetric method with automatic flow injection (AA3, BRAN+LUEBBE, Germany). Available phosphorus content was extracted in $0.5 \mathrm{M} \mathrm{NaHCO}_{3}$ and determined by $\mathrm{Mo}-\mathrm{Sb}$ colorimetry. Available potassium content was determined by method of flame photometry (Bao 2000).

\section{Data processing and analysis}

SPSS 17.0 and Origin8.0 (OriginLab Corporation) software were used for statistical analysis and plotting. Histograms were performed by SPSS 17.0 based on the residual distribution. We hypothesized the variance was homogeneous firstly. Then, homogeneity test of 
169

170

171

172

173

174

175

176

variance was performed by SPSS 17.0.If our hypothesis was true, one-way analysis of variance (ANOVA) following Fisher's least significant difference (LSD) test $(p<0.05)$ was used to compare the protection age effects on diversity of plant community and soil nutrients respectively.

\section{RESULTS}

\section{Diversity of plants in protected stands}

Data from 27 plots (Table 1) represented protection age of stands and richness of trees, shrubs and herbs (Table 2) were compared. Richness index of trees (8), shrubs (17) and herbs (35) was highest in the stand protected for 30 years (Table 2). A significant difference in the tree species richness index was observed in the 30 year protected stand compared to stands protected for 16 years $(\mathrm{n}=11, p=0.000)$ and 45 years $(. \mathrm{n}=14, p=0.000)$, but not in other stands with different protected ages (Figure 3).The richness index of within stand shrubs differed significantly between stands protected for 30 years compared to stands protected for 16 years $(\mathrm{n}=55, p=0.000), 45$ years $(\mathrm{n}=65, p=0.000), 60$ years $(\mathrm{n}=50, p=0.000)$ and 75 years $(\mathrm{n}=50, p=0.000)$ (Figure 3). Significant differences in the within-stand herb richness index were also found in stands protected (i) 16 years and 60, 75 years, (ii) 45 years and 60 years, 75 years (Figure 3). The within stand herb richness index in the stands protected for 30 years differentiated significantly from stands protected 16 years $(\mathrm{n}=55, p=0.000), 45$ years $(\mathrm{n}=65$, $p=0.000), 60$ years $(\mathrm{n}=50, p=0.000)$ and 75 years $(\mathrm{n}=50, p=0.000)$ (Figure 3$)$. Richness of within stand herb at stands protected for 16 years also varied significantly from stands protected for 60 years and 75 years (Figure 3). 
Shannon-Wiener evenness index of tree, shrub and herb was highest in stands protected for

191

30 years, 45 years and 75 years respectively (Figure $4 \mathrm{~A}$ ). The index of herb generally increased with protected ages except in stands protected for 16 years to 30 years (Figure 4A). However, the index of tree and shrub fluctuated with stand protected years and did not follow a trending relationship (Figure 4A). Tree and shrub Shannon-Wiener index increased with stand protection age, with the exception of tree index 30-45 year stand protection and shrub index 45-60 year stand protection (Figure 4A). To clearly show the trend of evenness index with age, linear fit of trees, shrubs and herbs was given out by Origin8.0 (OriginLab Corporation). With protection year increase, species distribution tended to be more homogeneous (Figure 4B).

\section{Biomass of Pinus tabulaeformis in protected stands}

Biomass of Pinus tabulaeformis increased in stands until 45 years of forest protection; however, for sites older than this protection age, stand biomass decreased (Figure 5). Peak biomass was $70.60 \pm 8.00 \mathrm{t}^{\mathrm{h}} \mathrm{ha}^{-1}$ in the stand protected for 45 years, while biomass in the stand protected for 75 years $\left(19.90 \pm 9.20 \mathrm{t}^{\cdot} \mathrm{ha}^{-1}\right)$ was lower than the standprotected for 16 years $(23.70$ $\left.\pm 17.10 \mathrm{t}^{\prime} \cdot \mathrm{ha}^{-1}\right)$ (Figure 5).

\section{Age structure of Pinus tabulaeformis population in protected stands}

Although age classes of Pinus tabulaeformis occurred in protected stands, they varied greatly (Figure6). Only young (II) and small trees (III) were found in the stand protected for 16 years, small (III) and medium trees (IV) dominated the stand protected for 30 years (Figure6). For the stand protected for 45 years, big ( V) and medium trees (IV) were main components, but seedlings ( I ) and young trees were considerable also (Figure6). In contrast, for stands protected 
211 for 60 and 75 years, seedlings ( I ) were the dominant component, followed by young( II ) and

212 small trees (III), with big trees ( V ) lowest in distribution (Figure6).

\section{Soil nutrients}

214 Significant differences of soil organic carbon content at 0-20 cm soil depth were observed

215 between the stands, with higher soil organic carbon content observed in stands protected for

216 longer than 30 years (Figure $7 \mathrm{~A}$ ). Content of mineral nitrogen at $0-20 \mathrm{~cm}$ soil depth

217 demonstrated significant differences in stands before and after the protected 30 years (Figure 7

218 B). No significant differences were found between stands protected for 16 years and 30 years,

219 and among stands after 30 years (Figure 7 B).Content of available phosphorus at 0-20 cm soil

220 depth increased as protection of stand age increased, with significant differences observed

221 mostly at youngest and oldest stand ages (Figure $7 \mathrm{C}$ ). No significant difference in available

222 phosphorus was observed in stands between 30 and 45 years of protection, and between 45 and

22360 years of protection (Figure 7 C).Content of available potassium at $0-20 \mathrm{~cm}$ soil depth

224 decreased in stands younger than 45 years and thereafter increased (Figure 7 D). Significant

225 differences were demonstrated among stands with different protection ages, except at ages 45

226 and 60 (Figure 7 D).

\section{Discussion}

\section{Response of plant diversity to forest protection}


231 herbs was significantly affected by forest protection, although richness (Figure 3) and evenness

232 (Figure 4) indices of tree, shrub and herb increased in an unpredictable manner with protected

233

234

236

237

238

239

240

241

242

243

244

245

246

247

248

249

250

251

age. The richness of plant species increased in stands protected for 16 years (species numbers of tree, shrub and herb are 3, 4 and 12 respectively) to 30 years (species numbers of tree, shrub and herb are 8, 16 and 35 respectively), decreased in stands protected for 30 years to 45 years (species numbers of tree, shrub and herb are 4, 5 and 14 respectively) and remained fairly stable in stands protected for longer than 45 years (species numbers of tree, shrub and herb are 6,8 and 17 respectively in stands protected for 60 years; species numbers of tree, shrub and herb are 5, 9 and 12 respectively in stands protected for 75 years) (Table 2). Due to adequate sunlight and growing spaces, some pioneer tree species (Populus davidiana, Betula platyphylla) and drought resistant shrubs (Rubus corchorifolius, Rosa hugonis, etc.) and herbs (Artemisia gmelinii, Saussurea petrovii, etc.) were more prevalent in the younger forest protection sites, increasing plant species richness of these stands (Table 2). With the growth of trees, canopy density increased and some drought resistant plant species disappeared. Advance regeneration seedlings in stands protected for 45 years and older made up a large proportion of the species observed, impeding invasive plant species and stabilizing plant diversity of the community assemblage. Inherent spatial variability within the landscape may provide a possible explanation for this pattern observed, since Pinus tabulaeformis stands are distributed across variable site conditions within the region. Soil moisture is considered to be the key limiting factor on the Loess Plateau for differences in plant species growth and regeneration(Chen et al. 2014) and it is possible that the differences in soil property as observed in this study affected plant-available 
252 moisture.

253 Forest protection in Huanglongshan forest region, Yanan, Shaanxi, China was initiated in

2541950 from forest resources archives. Stand structure within the protection area under the natural

255 restoration condition differed. Stands with diversified age structure were richer in species than

256 stands with less diversified structure (Thompson 2012). Findings in this study partly support this

257 notion. Stands protected for great than 16 years had more species with diverse age structures and

258 plant species richness (Figure 3). Age class structure in stands protected for 30 years were

259 generally simpler than stands protected for longer periods (Figure 6). However, stands older than

26030 years of protection had lower richness index of tress and understory species (Figure 4).

261 Our results suggest that sustainable forest protection can potentially contribute to plant

262 diversity conservation by increasing species richness generally (Table 2) and promoting even

263 distribution of trees and herbs (Figure 4).

264 Response of age structure to forest protection

265 Forest protection created more complex age structures (Figure 5) and tree densities with

266 increasing age of protection (Table1). Seedlings, medium and big trees were absent in younger

267 stands (Figure6) which indicated tree biomass was low (Figure 5) and lacked natural

268 regeneration capacity. Although plants species were most abundant in stands protected for 30

269 years (Figure 3), this protection age contained the lowest proportion of big trees ( V) among age

270 classes (Figure6) limiting tree biomass. Both seedlings (Figure6) and density of trees (Figure 3)

271 in older ( $>60$ years) protected stands were higher than in younger stands, suggesting a better

272 natural regeneration capacity. However, more seedlings and small trees without adequate big 
273

274 (Figure 5).

275

276

277

278

279

280

281

282

283

284

285

286

287

288

289

290

291

292

293

trees (Figure6) in some older stands were evidence of insufficient productivity of such stands

Our results support the widely accepted view that the rate of stand biomass accumulation peaks in the early stage of development, usually at the time of canopy closure, and declines

thereafter (Acker et al. 2002; Mcmahon \& Schlesinger 2010; Sarah Lesley Taylor 2005; Xu et al. 2012). The stand protected for 45 years had not only the highest canopy density (Table 1), but also the highest proportion of big trees and tree biomass as well as considerable seedling density

(Figure 6), suggesting adequate regeneration capacity at this age.

\section{Response of soil nutrients to forest protection}

Vegetation plays a key role in maintaining the soils in which they grow (Mishra et al.

2003), by directly influencing soil nutrients accumulation and consequently soil development via above ground inputs (Blazejewski et al. 2009; Drouin et al. 2011; Giese et al. 2000) . Litter fall and its decomposition is an important mechanism governing soil chemical properties (Mishra et al. 2003), especially the upper soil layer (Ma et al. 2007).

In the present study, Pinus tabulaeformis tree growth (Figure 5) and understory plant species richness increased quickly for stands protected less than30 years (Figure 3), however litter input to soil was lower due to the absence of big trees in these stands (Figure6). Tree and canopy density (Table 1) decreased in stands protected for more than 30 years, with highest values observed in stands protected for 45 years (Figure 5). Increased litter input, decomposition rate and higher soil organic carbon contents were also observed at older forest sites (Figure 7A). Content of soil mineral nitrogen at $0-20 \mathrm{~cm}$ soil depth showed a decreasing trend in stands 
294 of up to 30 years of protection although no significant differences were found among stands

295 (Figure 7B). This trend does not support previous studies which have observed that young or

296 developing stands accumulate forest floor nitrogen, tending towards relatively stable conditions

297 in undisturbed mature forests.

The primary source of phosphorus and potassium in terrestrial ecosystems are derived from mineral materials in weathering parent rock (Filippelli 2008; Sheng 2005; Smeck 1985; Tiessen et al. 1984). A proportion of the released phosphorus and potassium, available in exchangeable and soluble (available) fractions, can be assimilated by plants and soil microorganisms directly (Schachtman et al. 1998; Sheng 2005). Soil phosphorus availability is also enhanced through phosphorus solubilizing and mineralizing microbial biomass (Richardson \& Simpson 2011).

Many soil microorganisms excrete organic acids to directly dissolve rock potassium to bring the potassium into solution (Bennett 1998; Friedrich et al. 1991; Groudev 2010; Ullman et al. 1996).

In the present study, soil available phosphorus (Figure7C) and potassium (Figure 7D)

contents were higher in stands with greater proportions of big and medium trees. We suggest that

the stands with greater biomass accumulated more litter and humic mineral in the top soil, which

provided a substantial energy source and favorable conditions for microbial activity (Fontaine et

al. 2003). In younger stands, more nutrients may be taken up by the vegetation during intense

313 stands of up to 45 years of protection in this study (Figure 7D).

\section{The optimal age for the fully hillside-closed forest protection}


315 No restoration project is undertaken in a social vacuum (Knight et al. 2010). The goods and

316 services provided by forests are an important source of income for local people in the rural part

317 of China (Ma et al. 2013). Even when the intentions of ecological restoration are good and the

318 restoration strategy suitable for the environmental conditions (Ma et al. 2013), restoration action

319 will not be sustainable if it does not take into account the profit potential of local people.

320 Our results showed that long-term protection ( $>45$ years) of Pinus tabulaeformis stands in

321 southeast Loess Plateau, China, may be associated with decreasing plant species richness (Table

2), proportion of medium to large trees (Figure 6), dominant tree biomass (Figure 5) and soil

nutrients (Figure 7).In addition, proportion of seedlings was more than $45 \%$ when stands were

protected for 60 and 75 years (Figure 5). Forest tending operations are required to weaken

competition among seedlings for sunlight, nutrients, moisture and space at those periods. We

suggest that it is possible, based on the findings above, to couple forest management policy

without exacerbating the poverty of local people, through the promotion of measured forest

indices as evidence-based support for forest protection and use. For this region, we suggest the

optimum forest protection age of 45 years would encourage maximum plant diversity and

productivity, while supporting the socio-economic conditions of the local population for sustainable land use.

\section{Conclusions}

The present study has reported differences of plant diversity, changes in forest age structure

and soil nutrients of Pinus tabulaeformis stands restoration in chronosequence on the southeast

335 Loess Plateau, China. The richness of plant species significantly differed with age of forest 
336 protection, attenuating towards more even distribution with increasing age of forest protection.

337 Sustainable forest protection not only hindered increased biomass of dominant trees, organic

338 carbon content, available phosphorus and potassium in top soil, but it also abated proportion

339 medium and big trees after protection of 45 years. Meanwhile, proportion of seedlings and young

340 trees increased to aggravate competition of environmental resources. Our findings have practical

341 implications. By using measured forest indices as evidence-based support for balancing forest

342 management policy, ecological restoration and local economy development including sustainable

343 timber harvesting, we conclude that the preliminary optimal age for forest protection in this area

344 should be not more than 45 years. Forest tending operations have to be implemented thereafter.

\section{ACKNOWLEDGEMENTS}

346 We thank Mr. Ren-he Wang, Ms. Fen-ling Zhang and other staff in Huanglongshan Forest

347 Bureau, Yanan, Shaanxi, China for their valuable assistance. We also thank Dr. Diane Allen for

348 her comments.

349 ADDITIONAL INFORMATION AND DECLARATIONS

Data Availability

The following information was supplied regarding data availability. The summary data on which these analyses are based are available in Table 1 and Table 2. 


\section{REFERENCES}

354 Acker SA, Halpern CB, Harmon ME, and Dyrness CT. 2002. Trends in bole biomass

355

356

357

358

359

360

361

362

363

364

365

366

367

368

369

370

371

372

373

accumulation, net primary production and tree mortality in Pseudotsuga menziesii forests of contrasting age. Tree Physiology 22:213-217.

Aronson J, and Alexander S. 2013. Ecosystem restoration is now a global priority: Time to roll up our sleeves. Restoration Ecology 21:293-296.

Bao SD. 2000. Soil and Agricultural Chemistry Analysis. Beijing: China Agriculture Press.

Bennett PC. 1998. Microbial Destruction of Feldspars. Mineralogical Magazine 62A:149-150.

Bergen SD, Bolton SM, and L. Fridley J. 2001. Design principles for ecological engineering. Ecological Engineering 18:201-210.

Blazejewski GA, Stolt MH, Gold AJ, Gurwick N, and Groffman PM. 2009. Spatial distribution of carbon in the subsurface of riparian zones. Soil Science Society of America Journal 73:1733-1740.

Bock CE, Jones ZF, and Bock JH. 2007. Relationships between species richness, evenness, and abundance in a southwestern Savanna. Ecology 88:1322-1327.

Brais S, Camiré C, and Paré D. 1995. Impacts of whole-tree harvesting and winter windrowing on soil pH and. Canadian Journal of Forest Research 25:997-1007.

Chen C, and Peng H. 1996. Standing Crops and Productivity of the Major Forest-types at the Huoditang Forest Region of the Qinling Mountains. Journal of Northwest Forestry College 11:92-102.

Chen Y, Cao Y, Chen Y, and Cao Y. 2014. Response of tree regeneration and understory plant 
374

375

376

377

378

379

380

381

382

383

384

385

386

387

388

389

390

391

392

393

394

species diversity to stand density in mature Pinus tabulaeformis plantations in the hilly area of the Loess Plateau, China. Ecological Engineering 73:238-245.

Coroi M, Skeffington MS, Giller P, Smith C, Gormally M, and O'Donovan G. 2004. Vegetation diversity and stand structure in streamside forests in the south of Ireland. Forest Ecology \& Management 202:39-57.

Drouin A, Saint-Laurent D, Lavoie L, and Ouellet C. 2011. High-Precision Elevation Model to Evaluate the Spatial Distribution of Soil Organic Carbon in Active Floodplains. Wetlands 31:1151-1164.

Filippelli GM. 2008. The Global Phosphorus Cycle: Past, Present, and Future. Elements 4:89-95.

Fontaine S, Mariotti A, and Abbadie L. 2003. The priming effect of organic matter: a question of microbial competition? Soil Biology \& Biochemistry 35:837-843.

Friedrich S, Platonova NP, Karavaiko GI, Stichel E, and Glombitza F. 1991. Chemical and microbiological solubilization of silicates. Acta Biotechnologica 11:187-196.

Giese LA, Aust WM, Trettin CC, and Kolka RK. 2000. Spatial and temporal patterns of carbon storage and species richness in three South Carolina coastal plain riparian forests. Ecological Engineering 15:S157-S170.

Groudev SN. 2010. Use of heterotrophic microorganisms in mineral biotechnology. Engineering in Life Sciences 7:299-306.

Hillebrand H, Bennett DM, and Cadotte MW. 2008. Consequences of dominance: a review of evenness effects on local and regional ecosystem processes. Ecology 89:1510-1520.

Hooper DU, Chapin FS, Ewel JJ, Hector A, Inchausti P, Lavorel S, Lawton JH, Lodge DM, 
395

396

397

Loreau M, Naeem S, Setala H, Symstad A J, Vandermeer J, and Wardle D A. 2005.

Effects of biodiversity on ecosystem functioning: A consensus of current knowledge. Ecological

Monographs 75:3-35.

Huang XH, Yuan H, Yu FK, Li XY, Liang QB, Yao P, and Shao HB. 2014. Spatial-temporal succession of the vegetation in Xishuangbanna, China during 1976-2010: A case study based on RS technology and implications for eco-restoration. Ecological Engineering 70:255-262.

Kirwan L, Lüscher A, Sebastià MT, Finn JA, Collins RP, Porqueddu C, Helgadottir A, Baadshaug OH, Brophy C, Coran C, Dalmannsdóttir S, Delgado I, Elgersma A, Fothergill M, Frankow-Lindberg BE, Golinski P, Grieu P, Gustavsson AM, Höglind M, Huguenin-Elie O, Iliadis C, Jørgensen M, Kadziuliene Z, Karyotis T, Lunnan T, Malengier M, Maltoni S, Meyer V, Nyfeler D, Nykanen-Kurki P, Parente J, Smit HJ, Thumm U,and Connolly J. Evenness drives consistent diversity effects in intensive grassland systems across 28 European sites. Journal of Ecology 95:530-539.

Knight AT, Cowling RM, Mark D, and Campbell BM. 2010. Mapping human and social dimensions of conservation opportunity for the scheduling of conservation action on private land. Conservation Biology 24:1348-1358.

Ma H, Lv Y, and Li H. 2013. Complexity of ecological restoration in China. Ecological Engineering 52:75-78.

Ma X, Heal KV, Liu A, and Jarvis PG. 2007. Nutrient cycling and distribution in differentaged plantations of Chinese fir in southern China. Forest Ecology \& Management 
417 Magurran AE. 2004. Measuring Biological Diversity. Oxford: Blackwell Publishing.

418 Mcmahon SM, and Schlesinger WH. 2010. Evidence for a recent increase in forest growth. Proceedings of the National Academy of Sciences of the United States of America 107:3611-3615. of sodic soil by 3, 6 and 9 years old plantation of Eucalyptus tereticornis : Biorejuvenation of sodic soil. Forest Ecology \& Management 184:115-124.

Mitsch WJ. 2012. What is ecological engineering? Ecological Engineering 45:5-12.

Pan Y, Luo T, Birdsey R, Hom J, and Melillo J. 2004. New Estimates of Carbon Storage and Sequestration in China's Forests: Effects of Age-Class and Method On Inventory-Based Carbon Estimation'. Climatic Change 67:211-236.

Parker AJ, and Peet RK. 1984. Size and Age Structure of Conifers Forests. Ecology 65:16851689.

Richardson AE, and Simpson RJ. 2011. Soil Microorganisms Mediating Phosphorus Availability Update on Microbial Phosphorus. Plant Physiology 156:989-996.

Sarah Lesley Taylor DAM. 2005. Rate and causes of decline of mature and overmature balsam fir and spruce stands in New Brunswick, Canada. Canadian Journal of Forest Research $35: 2479-2490$.

Schachtman DP, Reid RJ, and Ayling SM. 1998. Phosphorus Uptake by Plants: From Soil to Cell. Plant Physiol 116:447-453. 
437 Sheng XF. 2005. Growth promotion and increased potassium uptake of cotton and rape by a potassium releasing strain of Bacillus edaphicus. Soil Biology \& Biochemistry 37:19181922.

Smeck NE. 1985. Phosphorus dynamics in soils and landscapes. Geoderma 36:185-199.

Thompson I. 2012. Biodiversity, ecosystem thresholds, resilience and forest degradation.

Wortley L, Hero J-M, and Howes M. 2013. Evaluating Ecological Restoration Success: A Review of the Literature. Restoration Ecology 21:537-543.

Xu CY, Turnbull MH, Tissue DT, Lewis JD, Carson R, Schuster WSF, Whitehead D, Walcroft AS, Li J, and Griffin KL. 2012. Age-related decline of stand biomass accumulation is primarily due to mortality and not to reduction in NPP associated with individual tree physiology, tree growth or stand structure in a Quercus -dominated forest. Journal of Ecology 100:428-440.

Xu J, Yin R, Li Z, and Liu C. 2006. China's ecological rehabilitation: Unprecedented efforts, 
459 Yin R, and Zhao M. 2012. Ecological restoration programs and payments for ecosystem services as integrated biophysical and socioeconomic processes - China's experience as an example. Ecological Economics 73:56-65.

462

463

464

465

466
Zhang Y, Chen HYH, and Reich PB. 2012. Forest productivity increases with evenness, species richness and trait variation: a global meta-analysis. Journal of Ecology 100:742749. 


\section{Table $\mathbf{1}$ (on next page)}

Table 1

General information of plots. 


\section{Table 1}

\begin{tabular}{|c|c|c|c|c|c|c|c|c|}
\hline Forest farm & $\begin{array}{l}\text { Plot } \\
\text { No. }\end{array}$ & $\begin{array}{c}\text { Altitude } \\
\text { (m) }\end{array}$ & Direction & $\begin{array}{l}\text { Gradient } \\
\left(^{\circ}\right)\end{array}$ & Position & $\begin{array}{c}\text { Density of } \\
\text { dominant tree } \\
\text { species } \\
\left(\text { trees } \cdot \mathrm{ha}^{-1} \text { ) }\right.\end{array}$ & $\begin{array}{l}\text { Canopy } \\
\text { density }\end{array}$ & $\begin{array}{c}\text { Protecting age } \\
\text { (a) }\end{array}$ \\
\hline \multirow{6}{*}{ Shibu } & 1 & 1170 & Southeast & 27 & Upper & 1025 & 0.30 & \multirow{6}{*}{16} \\
\hline & 2 & 1150 & Southeast & 29 & Middle & 1075 & 0.35 & \\
\hline & 3 & 1165 & Northeast & 24 & Middle & 1075 & 0.30 & \\
\hline & 4 & 1135 & Northeast & 26 & Lower & 1100 & 0.30 & \\
\hline & 5 & 1295 & North & 19 & Middle & 1050 & 0.30 & \\
\hline & 6 & 1154 & North & 22.3 & Middle & 1050 & 0.60 & \\
\hline \multirow{6}{*}{ Guanzhuang } & 7 & 1167 & Northwest & 24 & Lower & 675 & 0.50 & \multirow{6}{*}{30} \\
\hline & 8 & 1180 & South & 35 & Upper & 700 & 0.70 & \\
\hline & & & & & & & & \\
\hline & 9 & 1165 & South & 35 & Lower & 1350 & 0.60 & \\
\hline & 10 & 1180 & South & 22 & Upper & 1375 & 0.60 & \\
\hline & 11 & 1163 & South & 25 & Upper & 1050 & 0.50 & \\
\hline \multirow{7}{*}{ Wazijie } & 12 & 1170 & North & 24 & Upper & 750 & 0.60 & \multirow{7}{*}{45} \\
\hline & 13 & 1160 & North & 22.3 & Middle & 800 & 0.70 & \\
\hline & 14 & 1175 & North & 21 & Upper & 625 & 0.60 & \\
\hline & 15 & 1163 & North & 23 & Middle & 650 & 0.70 & \\
\hline & 16 & 1154 & North & 26 & Lower & 600 & 0.70 & \\
\hline & 17 & 1120 & & & $\begin{array}{l}\text { Gully } \\
\text { bottom }\end{array}$ & 730 & 0.70 & \\
\hline & 18 & 1130 & North & 10 & Lower & 760 & 0.60 & \\
\hline
\end{tabular}




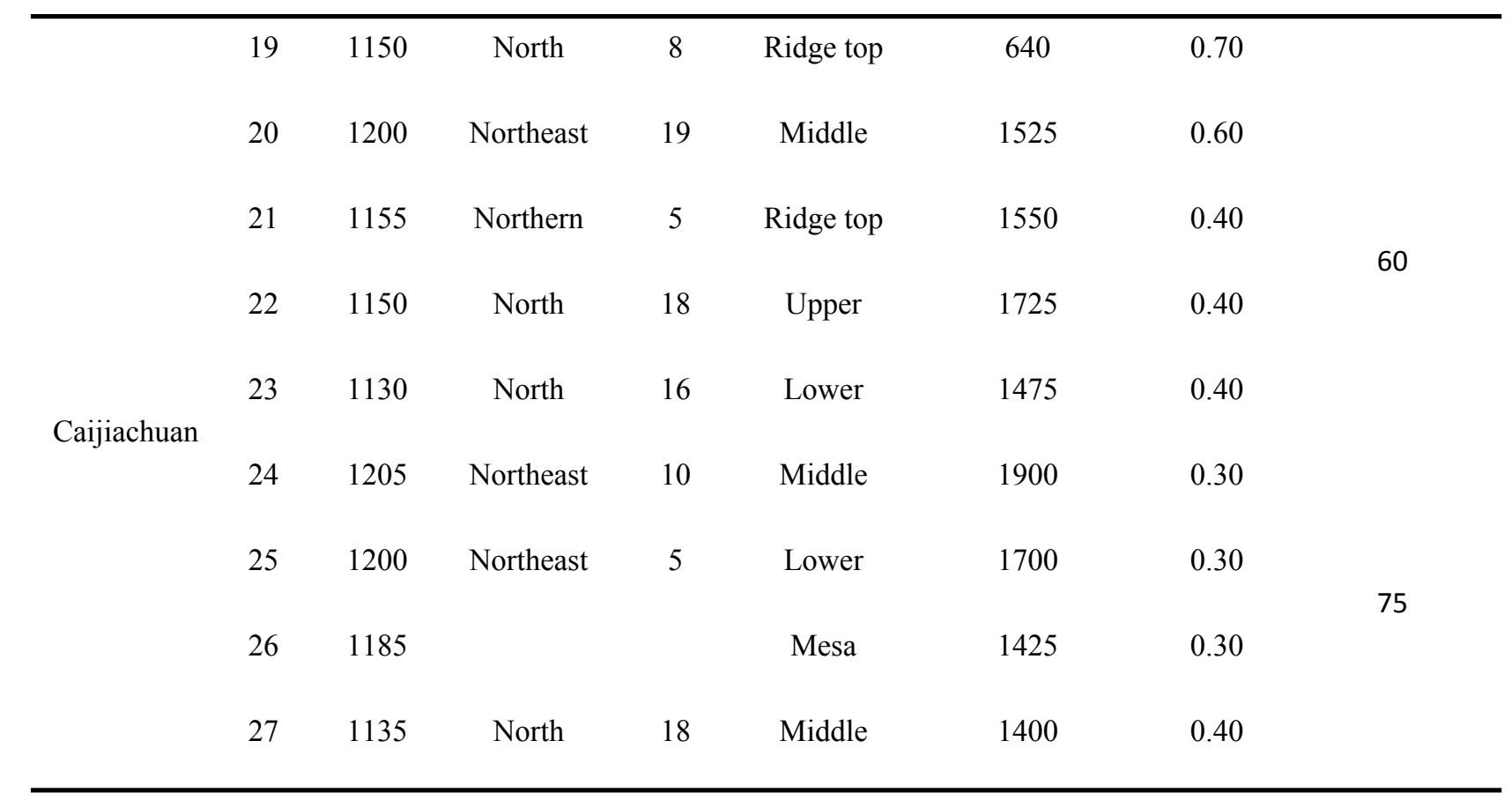




\section{Table 2 (on next page)}

Table 2

Richness of plant species in protected stands. 


\section{$1 \quad$ Table 2}

\begin{tabular}{|c|c|c|c|}
\hline Resoration age(a) & Tree & Shrub & Herb \\
\hline & Pinus tabulaeformis & Lespedeza dahurica & Astragalus kifonsanicus \\
\hline & Populus davidiana & Lespedeza floribunda & Artemisia mongolica \\
\hline & Syringa oblata & Rosa hugonis & Artemisia giraldii \\
\hline & & Sophora viciifolia & Aster tataricus \\
\hline & & & Bothriochloa ischaemum \\
\hline \multicolumn{4}{|l|}{16} \\
\hline & & & Bupleurum chinense \\
\hline & & & Kengia serotina \\
\hline & & & Lamium barbatum \\
\hline & & & Patrinia heterophylla \\
\hline & & & Rhaponticum uniflorum \\
\hline & & & Scutellaria baicalensis \\
\hline & & & Viola chaerophylloides \\
\hline & Betula platyphylla & Acer ginnala & Adenophora potaninii \\
\hline & Conus walteri wanger & Berberis dielsiana & Adenophora stricta \\
\hline & Pinus tabulaeformis & Clematis brevicaudata & Agrimonia pilosa \\
\hline \multirow[t]{4}{*}{30} & Prunus davidiana & Clematis fruticosa & Anaphalis margaritacea \\
\hline & Prunus tomenosa & Cotoneaster multiflorus & Artemisia giraldii \\
\hline & Xanthoceras sorbifolia & Lespedeza dahurica & Artemisia gmelinii \\
\hline & Quercus Liaotungensis & Lonicera ferdinandii & Artemisia mongolica \\
\hline
\end{tabular}


Ostryopsis davidiana

Periploca sepium

Rhamnus davurica

Rhamnus utilis

Rosa hugonis

Rubus corchorifolius

Sophora viciifolia

Spiraea fritschiana

Ziziphus jujube

var.spinosus
Aster tataricus

Bothriochloa ischaemum

Bupleurum chinense

Carpesium divaricatum

Discorea nippnica

Gentiana macrophylla

Kengia serotina

Leontopodium leontopodioides

Lilium pumilum

Lysimachia barystachys

Melissitus ruthenicus

Patrinia heterophylla

Pennisetum clandestinum

Polygonatum odoratum

Potentilla supina

Sanguisorba officinalis

Saussurea morifolia

Saussurea nivea

Saussurea petrovii

Saussurea salsa

Scutellaria baicalensis 


\begin{tabular}{|c|c|c|c|}
\hline & & & Spodiopogon sibiricus \\
\hline & & & Thalictrum prezewalskii \\
\hline & & & Urena lobata \\
\hline & & & Vicia unijuga \\
\hline & & & Viola chaerophylloides \\
\hline & & & Viola selkirkii \\
\hline & & & Viola yedoensis \\
\hline \multirow{15}{*}{45} & Betula platyphylla & Acer ginnala & Agrimonia pilosa \\
\hline & Pinus tabulaeformis & Lespedeza dahurica & Anaphalis margaritacea \\
\hline & Quercus Liaotungensis & Lonicera maccki & Artemisia mongolica \\
\hline & Syringa oblata & Rubus corchorifolius & Aster tataricus \\
\hline & & Spiraea fritschiana & Bothriochloa ischaemum \\
\hline & & & Kengia serotina \\
\hline & & & Neottianthe cucullata \\
\hline & & & \\
\hline & & & Potentilla discolor \\
\hline & & & Spodiopogon sibiricus \\
\hline & & & Urena lobata \\
\hline & & & Viola chaerophylloides \\
\hline & & & Viola japonica var. stenopetala \\
\hline & & & Viola selkirkii \\
\hline & & & Viola yedoensis \\
\hline
\end{tabular}




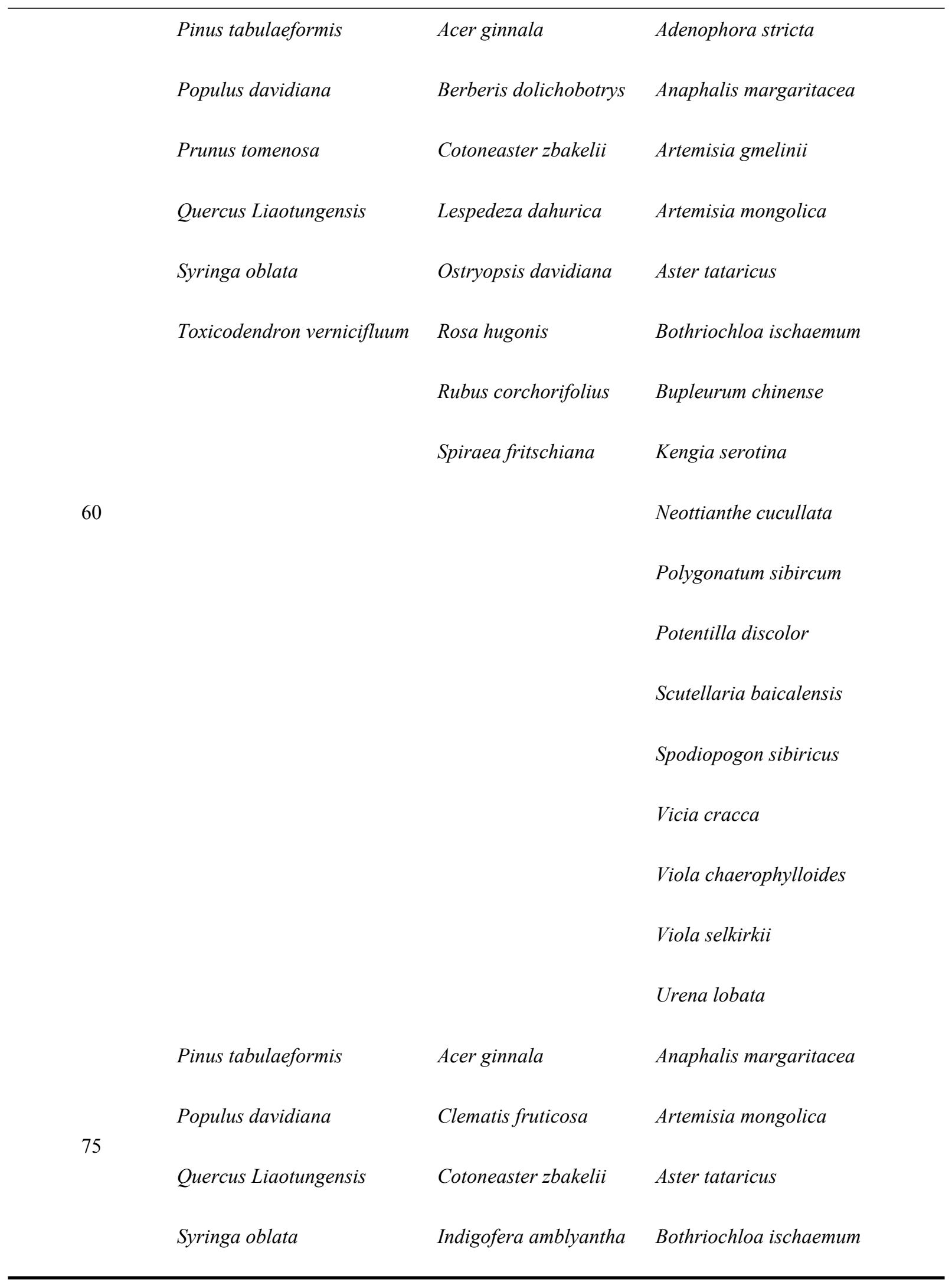




\begin{tabular}{lll}
\hline Toxicodendron vernicifluum & Lespedeza dahurica & Kengia serotina \\
& Lonicera maccki & Sanguisorba officinalis \\
& Ostryopsis davidiana & Spodiopogon sibiricus \\
& Rubus corchorifolius & Thalictrum prezewalskii \\
& Spiraea fritschiana & Urena lobata \\
& Viola chaerophylloides \\
& Vicia unijuga \\
& Viola selkirkii \\
\hline
\end{tabular}

2

3

4 
Figure 1

Figure 1

Position of plots. Dots on the figure were plots chosen in each forest farm.

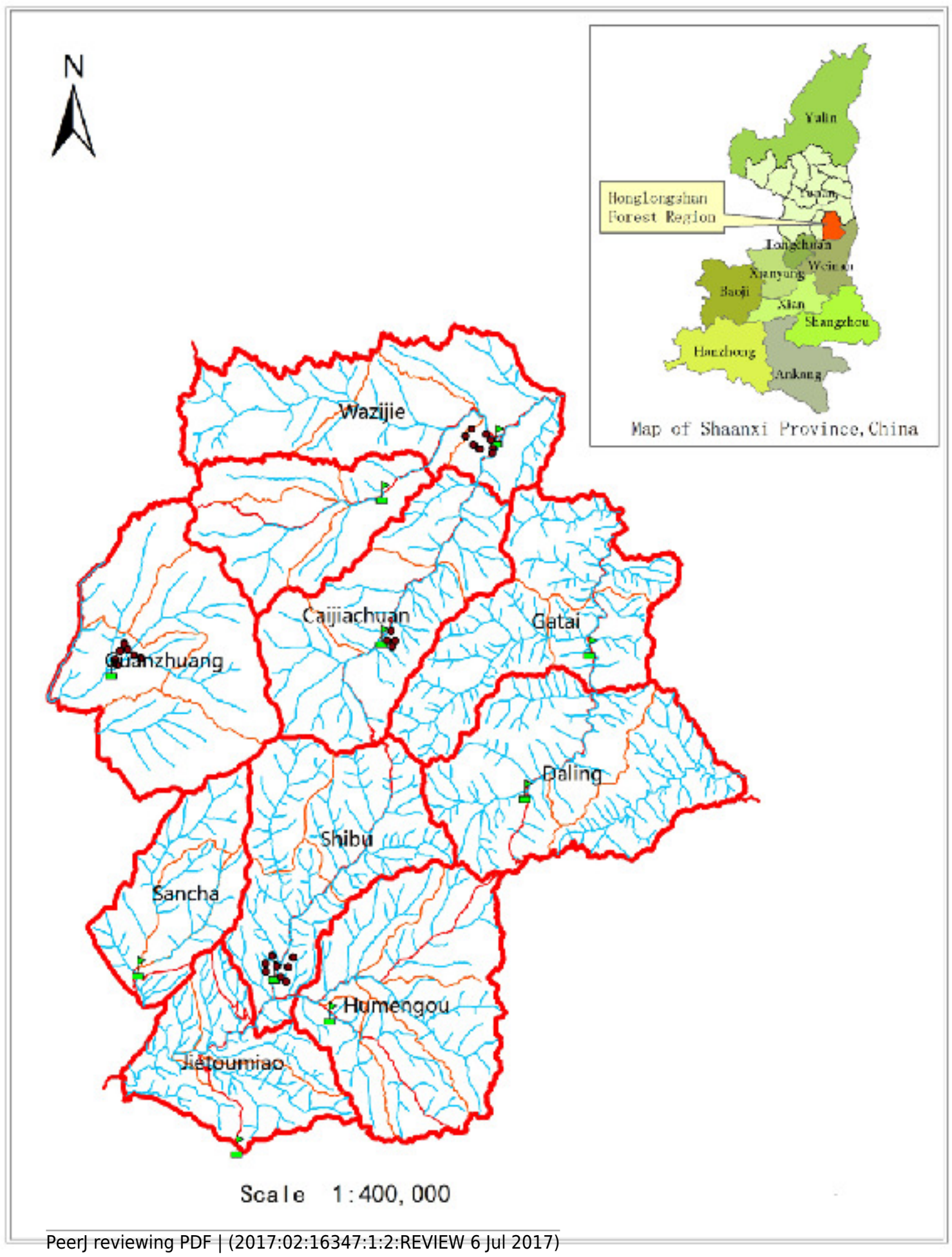


Figure 2

Figure 2

Layout of subplots. The plots were $20 \mathrm{~m} \times 20 \mathrm{~m}$, the subplots $2 \mathrm{~m} \times 2 \mathrm{~m}$ and $1 \mathrm{~m} \times 1 \mathrm{~m}$ and were used for the investigation of trees, shrubs and herbs respectively.

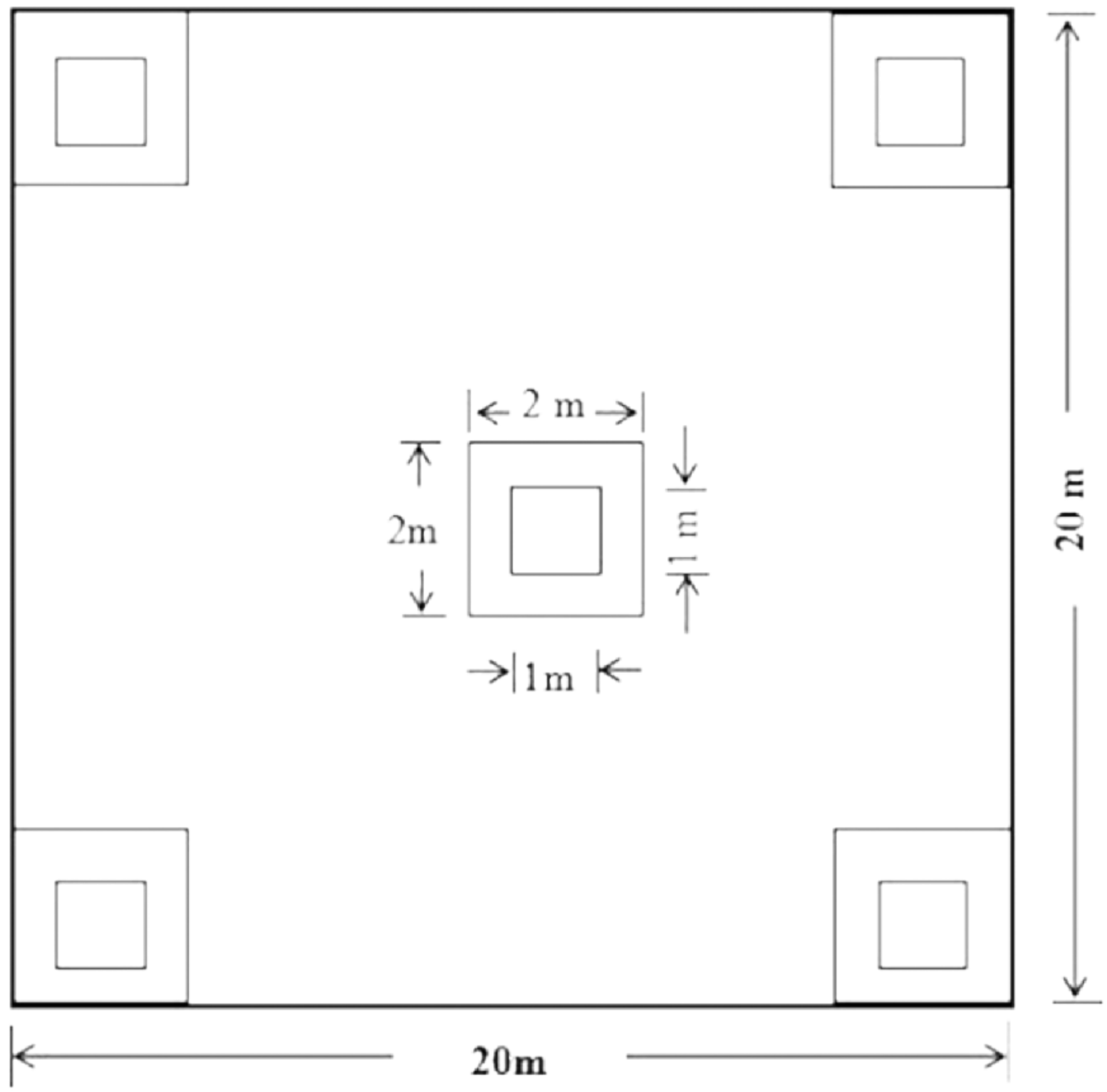


Figure 3

Figure 3

Richness of Pinus tabulaeformis community in protected stands. The values are the mean $\pm S D$. Different letters in the same layer in the figure indicate significant differences between groups based on LSD $(p<0.05)$. Confidence interval of $95 \%$ for richness of tress, shrubs and herbs among protection years is [3.32,7.48], [2.03,14.37] and [5.93,30.07] respectively.

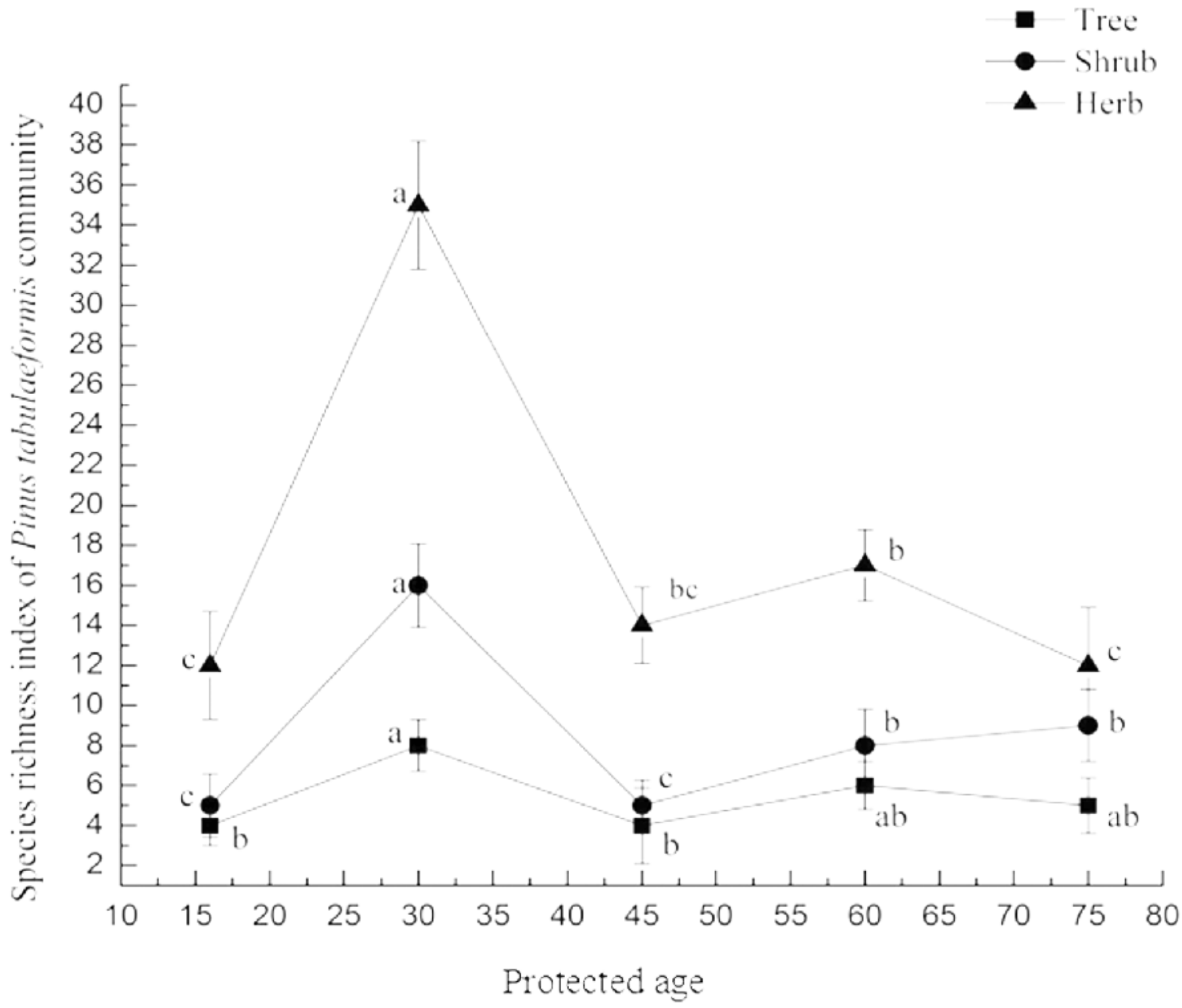




\section{Figure 4}

Figure 4

Shannon-Wiener evenness index of Pinus tabulaeformis community in protected stands. Letters ET, ES, EH and $\mathrm{a}$ in Figure 4B stand for the evenness index of tree, shrub, herb and protection year respectively. Confidence interval of $95 \%$ for evenness of tress, shrubs and herbs is [0.16, 0.85], [0.60, 0.99] and [0.16, 0.64 ] respectively. Equations in Figure $4 \mathrm{~B}$ show the relationship between evenness index and protected year of stands. $E_{T}, E s, E_{H}$ show a represented evenness index of tree, shrub, herb and protected year of stands, respectively.
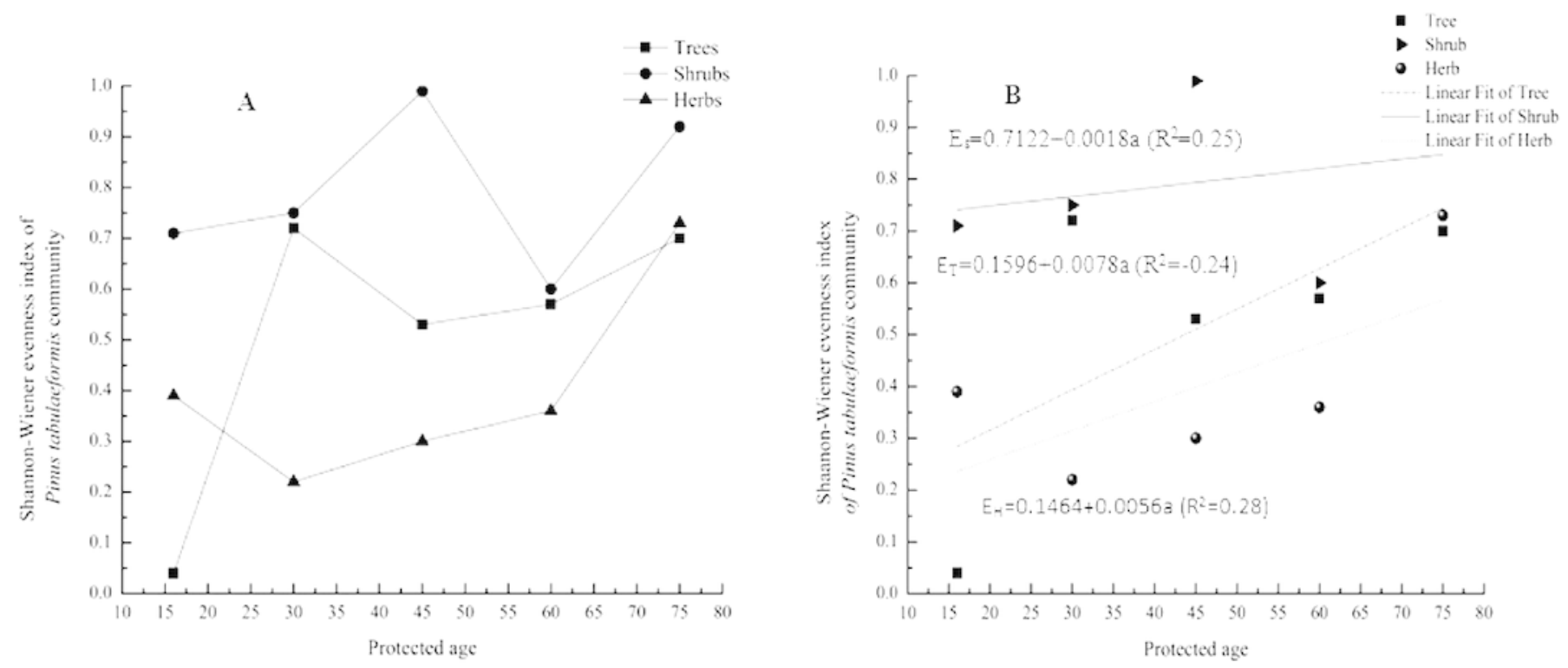
Figure 5

Figure 5

Biomass of Pinus tabulaeformis in protected stands. Error bars are from one-way analysis of variance (ANOVA). Confidence interval of $95 \%$ for biomass of dominant tress is [22.87, 74.25].

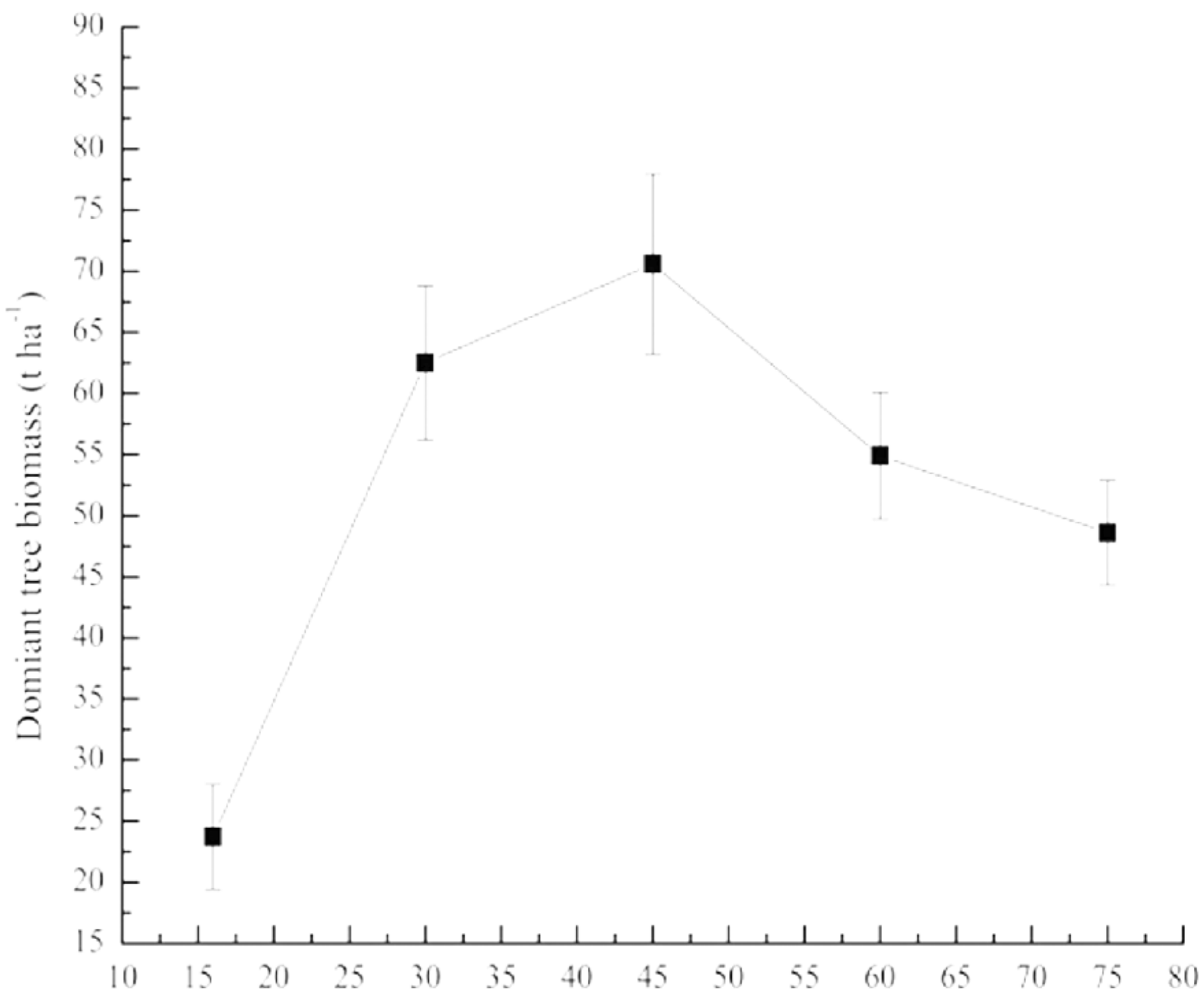




\section{Figure 6}

Figure 6

Age structure of Pinus tabulaeformis population in protected stands. The Roman numerals (IV) in figures stand for age structures of Pinus tabulaeformis population. Iseedling, $\mathrm{H} \leq 0.30 \mathrm{~m}$; Ilyoung tree, $0.30 \mathrm{~m} 2.0 \mathrm{~m}, 6.0 \mathrm{~cm}<\mathrm{DBH} \leq 12.0 \mathrm{~cm}$; IV medium tree, $12.0 \mathrm{~cm}<\mathrm{DBH} \leq 20.0$ $\mathrm{cm}$; V big tree, $\mathrm{DBH}>20.0 \mathrm{~cm}$.
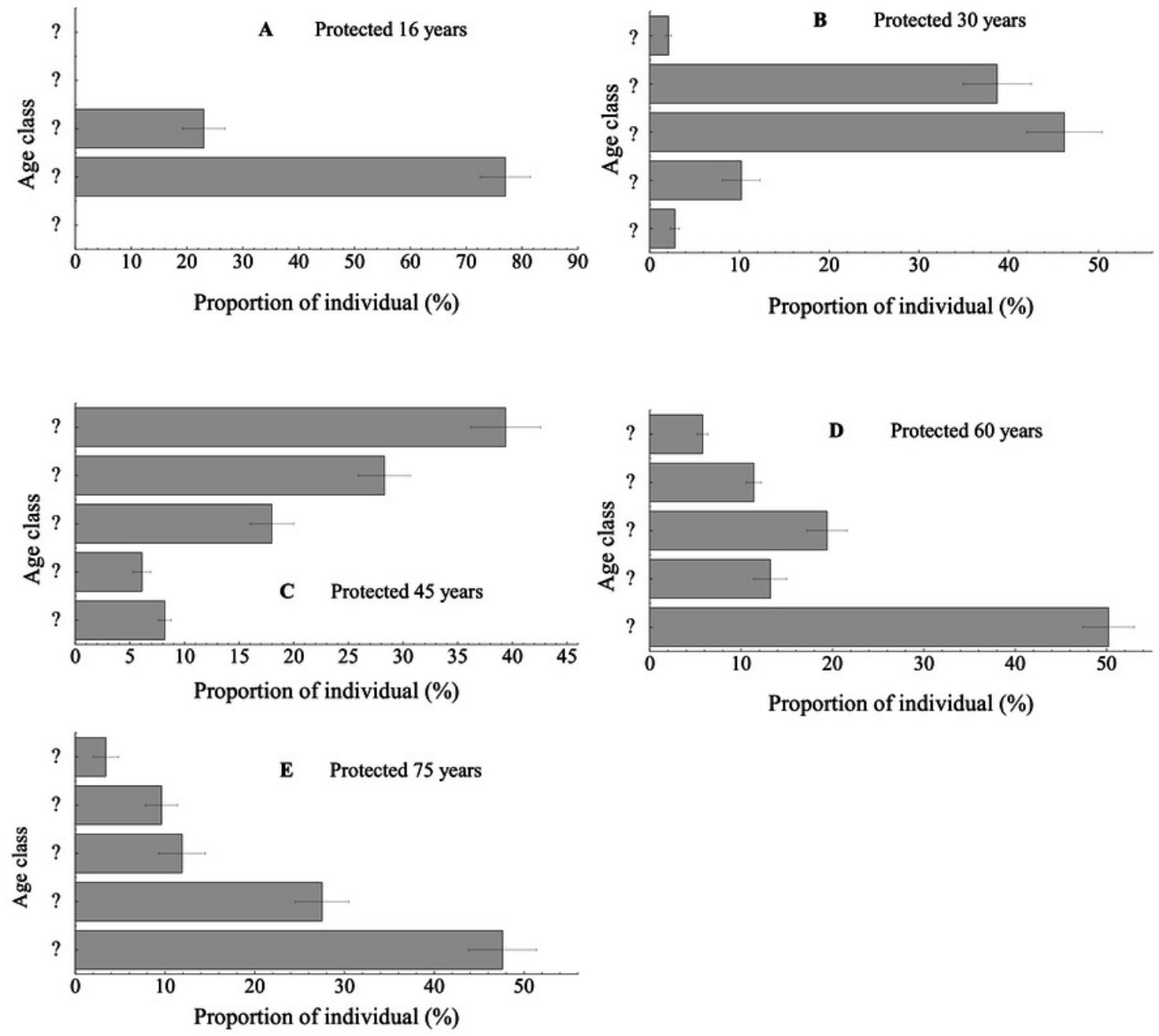


\section{Figure 7}

Figure 7

Soil nutrients in protected stands. The subfigures A, B, C and D demonstrate the dynamics of soil organic carbon ( $\mathrm{gkg}-1$ ), soil mineral nitrogen (mgkg-1), soil available phosphorus ( $\mathrm{mgkg}$ 1) and soil available potassium (mgkg-1) with protection of stands, respectively. Disparate lowercase letters on the figure represent significant difference $(p<0.05)$.
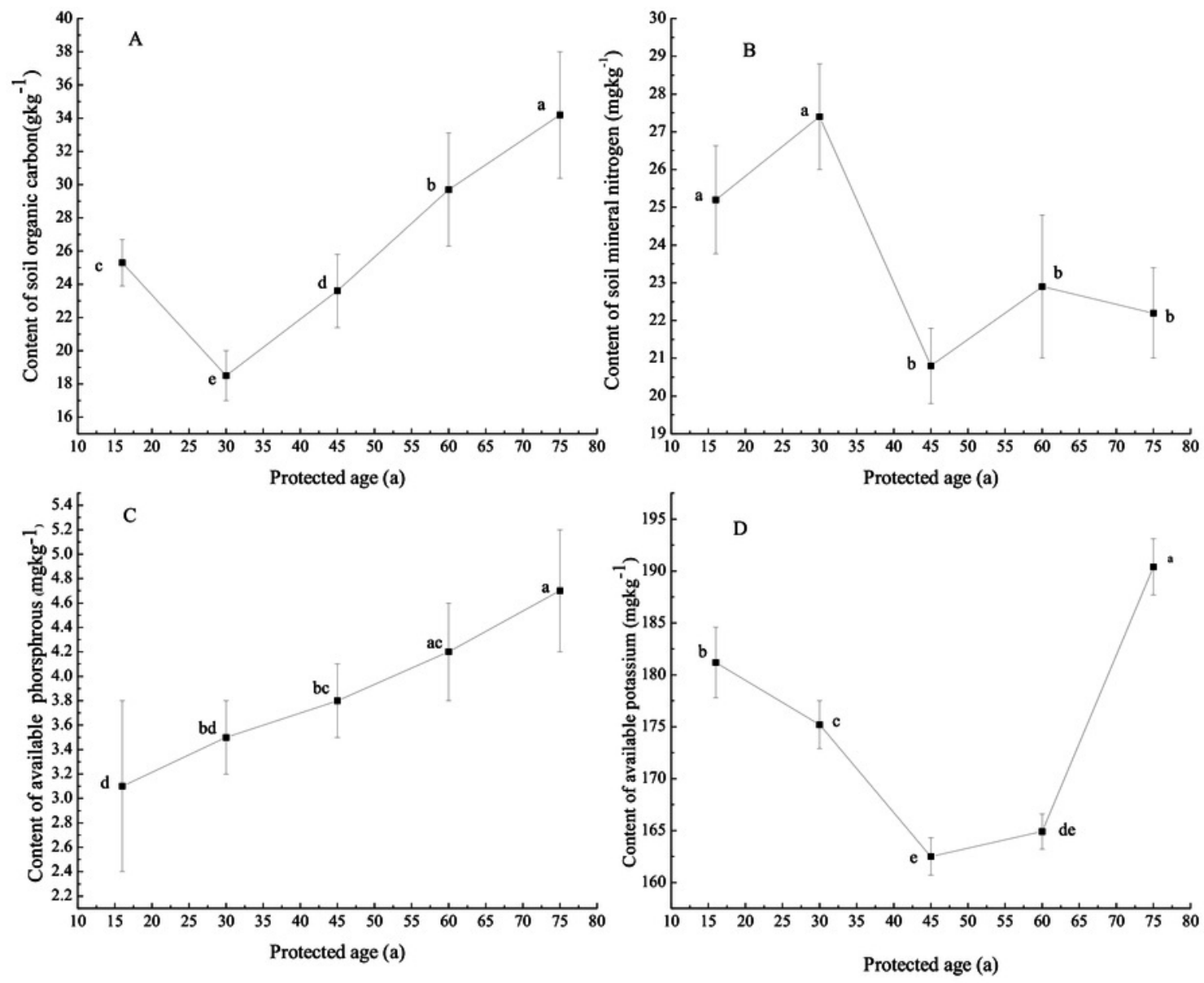